\title{
Peningkatan Kualitas Crude Glycerol dengan Proses Adsorpsi menggunakan Sekam Padi
}

\section{Improving the Quality of Crude Glycerol with Adsorption Process using Rice Husk}

\author{
Isalmi Aziz ${ }^{1}$, Muhammad Nizar Aristya ${ }^{1}$, Hendrawati $^{1}$, Lisa Adhani ${ }^{2}$ \\ ${ }^{1}$ Program Studi Kimia, FST UIN Syarif Hidayatullah Jakarta \\ J1 Ir.H. Juanda No 95 Ciputat Tangerang Selatan 15412, Indonesia \\ ${ }^{2}$ Jurusan Teknik Kimia Universitas Bayangkara, Bekasi Jawa Barat 12140, Indonesia
}

Email: isalmikimia@uinjkt.ac.id

Received: March 2018; Revised: April 2018; Accepted: April 2018; Available Online: May 2018

\begin{abstract}
Abstrak
Crude glycerol merupakan produk samping pembuatan biodiesel dengan kemurnian yang rendah karena masih mengandung senyawa pengotor seperti metanol, asam lemak bebas, katalis dan air. Senyawa pengotor ini harus dihilangkan supaya kualitas gliserol meningkat dan punya nilai jual yang tinggi. Adsorpsi merupakan salah satu metoda yang dapat digunakan untuk menyerap senyawa pengotor tersebut. Pada penelitian ini digunakan sekam padi sebagai adsorben karena mengandung selulosa. Selain itu sekam padi merupakan limbah, sehingga pemanfaatannya sebagai adsorben akan dapat menekan biaya proses pemurnian crude glycerol. Penelitian ini bertujuan untuk menentukan kondisi optimum proses (waktu, suhu, konsentrasi adsorben dan ukuran adsorben), kualitas gliserol yang dihasilkan dan karaktersitik adsorben sebelum dan sesudah adsorpsi (FTIR dan SEM). Crude glycerol terlebih dahulu diasamkan menggunakan asam fosfat dan selanjutnya diekstraksi menggunakan metanol. Crude glycerol hasil ekstraksi selanjutnya dilakukan adsorpsi menggunakan sekam padi yang sudah diaktivasi. Hasil adsorpsi disaring dan ditentukan kadar gliserolnya. Hasil penelitian menunjukkan bahwa kondisi optimum adsorpsi diperoleh pada waktu 75 menit, suhu $90{ }^{\circ} \mathrm{C}$, konsentrasi adsorben $20 \%$ dan ukuran adsorben $180 \mu \mathrm{m}$. Kualitas gliserol yang dihasilkan memiliki kadar gliserol $97.290 \%$, air $1.698 \%$, abu $0.885 \%$, MONG $0.132 \%$, tidak mengandung gula. Spektrum FTIR sebelum adsorpsi menunjukkan adanya gugus $\mathrm{O}-\mathrm{H}$, $\mathrm{C}=\mathrm{O}, \mathrm{C}=\mathrm{C}$ dan $\mathrm{C}-\mathrm{O}$ dan setelah adsorpsi terjadi penambahan gugus $\mathrm{C}-\mathrm{H}$ alifatik. Morfologi adsorben sebelum adsorpsi memperlihatkan pori-pori yang terbuka dan setelah adsorpsi pori-pori tersebut tertutupi oleh senayawa pengotor.
\end{abstract}

Kata kunci: Crude glycerol, adsorpsi, sekam padi.

\begin{abstract}
Crude glycerol is a byproduct of biodiesel with a low purity because it still contains impurities such as methanol, free fatty acids, catalyst, and water. This impurity compound should be removed so that the quality of glycerol increases and has a high selling value. Adsorption is one method that can be used to absorb the impurity compound. In this study used rice husk as an adsorbent because it contains cellulose. In addition, rice husk is waste, so its utilization as an adsorbent will be able to reduce the cost of purification process of crude glycerol. This study aims to determine the optimum conditions of the process (time, temperature, adsorbent concentration and size of adsorbent), quality of glycerol produced and adsorbent prior and after adsorption (FTIR and SEM). Crude glycerol is first acidified using phosphoric acid and subsequently in extraction using methanol. Crude glycerol further extraction results in adsorption using rice husks that have been activated. The adsorption result was filtered and the glycerol content was determined. The results showed that the optimum condition of adsorption was obtained at 75 minutes, temperature 90
\end{abstract}


${ }^{\circ} \mathrm{C}, 20 \%$ adsorbent concentration, and $180 \mu \mathrm{m}$ adsorbent size. The quality of glycerol produced has $97.290 \%$ glycerol content, $1.698 \%$ water, $0.885 \%$ ash, $0.132 \%$ MONG, no sugar. The FTIR spectrum prior to adsorption showed the presence of $\mathrm{O}-\mathrm{H}, \mathrm{C}=\mathrm{O}, \mathrm{C}=\mathrm{C}$ and $\mathrm{C}-\mathrm{O}$ groups and after adsorption, an addition of aliphatic $\mathrm{C}-\mathrm{H}$ groups. The adsorbent morphology before adsorption shows open pores and after adsorption, the pores are covered by impurity compounds.

Keyword: Crude glycerol, adsorption, rice husk.

DOI: http://dx.doi.org/10.15408/jkv.v4i1.7498

\section{PENDAHULUAN}

Biodiesel adalah salah satu energi alternatif pengganti petroleum diesel atau solar yang berasal dari bahan bakar minyak bumi atau fosil. Biodiesel dibuat melalui reaksi transesterifikasi minyak tumbuhan atau lemak hewan dengan alkohol (Adhani et al., 2016). Seiring meningkatnya produksi biodiesel di Indonesia, meningkat pula produk samping dari biodiesel yaitu gliserol. Gliserol yang dihasilkan memiliki tingkat kemurnian yang rendah yang disebut gliserol kasar atau crude glycerol. Crude glycerol bercampur dengan pengotor sehingga belum dapat dimanfaatkan dan hanya akan menjadi limbah jika tidak dilakukan proses pemurnian.

Adsorpsi adalah salah satu cara yang efektif dalam metode pemurnian. Adorpsi merupakan proses penyerapan pada lapisan permukaan atau antar fasa, dimana molekul dari suatu materi terkumpul pada bahan pengadsorpsi atau adsorben (Atkins, 1998). Penggunaan adsorpsi dalam peningkatan kualitas crude glycerol, dapat mengurangi senyawa pengotornya sehingga kualitas crude glycerol menjadi lebih baik. Pemurnian crude glycerol menggunakan proses adsorpsi sebelumnya telah dilakukan oleh Fadhillah et al., (2017) menggunakan zeolit dan tawas. Konsentrasi gliserol yang didapatkan $93.803 \%$. Manosak et al., (2011) juga melakukan pemurnian crude glycerol menggunakan kombinasi proses kimia dan adsorpsi menggunakan karbon aktif komersil, dimana kadar gliserol tertinggi yang dihasilkan sebesar 95.74\%. Karbon aktif memiliki kemampuan adsorpsi yang sangat baik dalam pemurnian crude glycerol. Karbon aktif atau disebut juga arang aktif berfungsi sebagai adsorben yang dapat dibuat dari biomassa (biosorben). Penggunaan biomasa sebagai bahan dasar karbon aktif memiliki beberapa keunggulan diantaranya lebih murah dan dapat mengurangi limbah biomasa. Salah satu limbah biomasa yang dapat digunakan sebagai bahan dasar karbon aktif untuk keperluan biosorben adalah sekam padi. Sekam padi terdiri atas unsur organik seperti selulosa, hemiselulosa dan lignin. Selain itu, sekam padi juga mengandung unsur anorganik seperti silika, kalium, kalsium, besi, fosfat dan magnesium. Jika dilakukan aktifasi, selain material berpori yang dhasilkan juga terdapat gugus aktif yaitu Si-O-Si dan Si-OH (Nurhasni, et al., 2014).

Pada penelitian ini, untuk meningkatkan kualitas crude glycerol, maka digunakan sekam padi yang sudah diaktivasi sebagai adsorben. Proses adsorpsi dilakukan dengan memvariasikan waktu, suhu, konsentrasi adsorben dan ukuran partikel adsorben. Gliserol yang dihasilkan pada kondisi optimum proses selanjutnya ditentukan sifat fisik dan kimianya berdasarkan SNI 061564-1995.

\section{METODE PENELITIAN}

\section{Alat dan Bahan}

Alat yang digunakan pada penelitian ini adalah alat-alat gelas, termometer, hot plate, magnetic stirrer, oven, piknometer, desikator furnace, pompa vakum, spektrofotometer UV-Vis Perkin Elmer Lamda 25, Scanning Electron Microscopy (SEM) Hitachi SU3500, Fourier Transform Infrared (FTIR) Shimadzu IR Pretige-21 dan Atomic Absorption Spectroscopy (AAS) Shimadzu AA-6800.

Bahan yang digunakan adalah minyak goreng bekas yang berasal dari salah satu rumah makan di daerah Ciputat, Tangerang Selatan; sekam padi kering yang berasal dari kampung Leles Kelurahan Sindangsari Kecamatan Pasarkemis Kabupaten Tangerang; $\mathrm{KOH}$ p.a (Merck); $\mathrm{CH}_{3} \mathrm{OH}$ teknis; aquadest; $\mathrm{H}_{3} \mathrm{PO}_{4} 85 \%$ p.a (Merck); $\mathrm{NaOH}$ p.a (Merck); 
bromtimol biru; $\mathrm{HCl}$ p.a (Merck); $\mathrm{NaIO}_{4}$ p.a (Merck) dan etilen glikol p.a (Merck).

Aktivasi Sekam Padi (Nurhasni et al., 2014)

Sekam padi dicuci dengan air sampai bersih dan dijemur di bawah terik matahari hingga kering. Sekam padi yang telah kering selanjutnya diarangkan pada suhu $250{ }^{\circ} \mathrm{C}$ selama 2.5 jam menggunakan furnace. Kemudian sekam padi dihaluskan, diayak dan selanjutnya digunakan sebagai adsorben. Adsorben yang dihasilkan selanjutnya dikarakterisasi menggunakan Fourier Trnasform Infrared (FTIR) untuk melihat perubahan gugus fungsi sebelum dan sesudah adsorpsi dan Scanning Electron Microscopy (SEM) untuk melihat morfologi permukaan adsorben.

\section{Pembuatan Crude Glycerol (Aziz et al., 2008)}

Sebanyak $2 \mathrm{~g} \mathrm{KOH}$ dilarutkan dalam $50 \mathrm{~mL}$ metanol. Kemudian dipanaskan minyak goreng bekas sebanyak $200 \mathrm{~mL}$ sampai suhu $60{ }^{\circ} \mathrm{C}$, setelah suhu konstan ditambahkan larutan metanol-KOH dan diaduk menggunakan magnetic stirrer diatas hotplate. Laju pengadukannya diatur pada $700 \mathrm{rpm}$ kemudian dibiarkan selama 60 menit dan dijaga suhunya agar tetap konstan. Hasil reaksi dimasukkan ke dalam corong pisah, kemudian dibiarkan selama 24 jam sampai terjadi pemisahan yang sempurna. Lapisan atas merupakan lapisa biodiesel dan lapisan bawah adalah crude glycerol.

\section{Proses Pengasaman dan Ekstraksi (Manosak et al., 2011) \\ Crude glycerol diasamkan dengan} larutan $\mathrm{H}_{3} \mathrm{PO}_{4} \quad 85 \%$ hingga mencapai $\mathrm{pH}$ larutan \pm 2.5 , setelah itu crude glycerol didiamkan selama \pm 12 jam sampai larutan membentuk 3 fasa. Lapisan paling atas merupakan gumpalan asam lemak bebas, lapisan tengah adalah gliserol, dan lapisan paling bawah adalah endapan garam anorganik. Setelah terjadi pemisahan, lapisan gliserol dipisahkan dari endapan garam maupun asam lemak bebas dengan cara penyaringan.

Lapisan gliserol yang didapat setelah pengasaman dinetralkan dengan menggunakan $\mathrm{NaOH} 5 \mathrm{M}$ sampai $\mathrm{pH}$ 7.0. Kemudian lapisan gliserol didiamkan sampai terbentuk dua lapisan yaitu lapisan bawah adalah endapan sisa garam dan lapisan atas adalah gliserol, kemudian lapisan gliserol difiltrasi untuk memisahkannya. Selanjutnya lapisan gliserol yang telah dipisahkan diekstrak dengan penambahan metanol dengan perbandingan metanol:gliserol yaitu 2:1 (v/v). Campuran diaduk selama 30 menit dan didiamkan selama satu jam sampai terbentuk dua lapisan yaitu lapisan atas gliserol-alkohol dan lapisan bawah endapan garam kristal. Kemudian lapisan gliserolalkohol dipisahkan dari endapan garam dengan penyaringan dan selanjutnya dievaporasi pada suhu $60{ }^{\circ} \mathrm{C}$ selama 20 menit untuk menguapkan pelarut (metanol).

\section{Penentuan Kondisi Optimum Proses Adsorpsi}

Sekam padi ukuran $250 \mu \mathrm{m}$ dicampurkan ke dalam gliserol hasil ekstraksi dengan konsentrasi $20 \% \quad(\mathrm{w} / \mathrm{v})$, kemudian diaduk dengan kecepatan $200 \mathrm{rpm}$ pada variasi suhu adsorpsi $30,45,60,75$ dan $90^{\circ} \mathrm{C}$. Pada masing-masing variasi suhu dilakukan proses adsorpsi dengan variasi waktu 30, 60, 75, 90 dan 120 menit kemudian disaring dan dianalisis kadar gliserol menggunakan metoda SNI 06-1564-1995. Selanjutnya suhu dan waktu adsorpsi optimum digunakan sebagai variabel tetap dalam penentuan konsentrasi biosorben optimum dengan variasi konsentrasi biosorben $0,10,15,20,25$ dan $30 \%(\mathrm{w} / \mathrm{v})$. Kemudian suhu, waktu adsorpsi dan konsentrasi biosorben optimum digunakan sebagai variabel tetap pada penentuan ukuran partikel biosorben optimum dengan variasi ukuran 180, 250 dan $630 \mu \mathrm{m}$. Gliserol yang dihasilkan pada kondisi optimum selanjutnya dianalisis kadar air (AOAC 1995), kadar abu (AOAC 1995), kadar gula (SNI 06-1564-1995), densitas dan dan kadar kalium (SNI 06-6989-2005).

\section{HASIL DAN PEMBAHASAN}

\section{Pengaruh Waktu dan Suhu Adsorpsi}

Waktu dan suhu pada proses adsorpsi dapat mempengaruhi adsorpsi senyawa pengotor yang terdapat dalam crude glycerol. Pada Gambar 1 dapat dilihat bagaimana waktu dan suhu mempengaruhi kadar gliserol. 


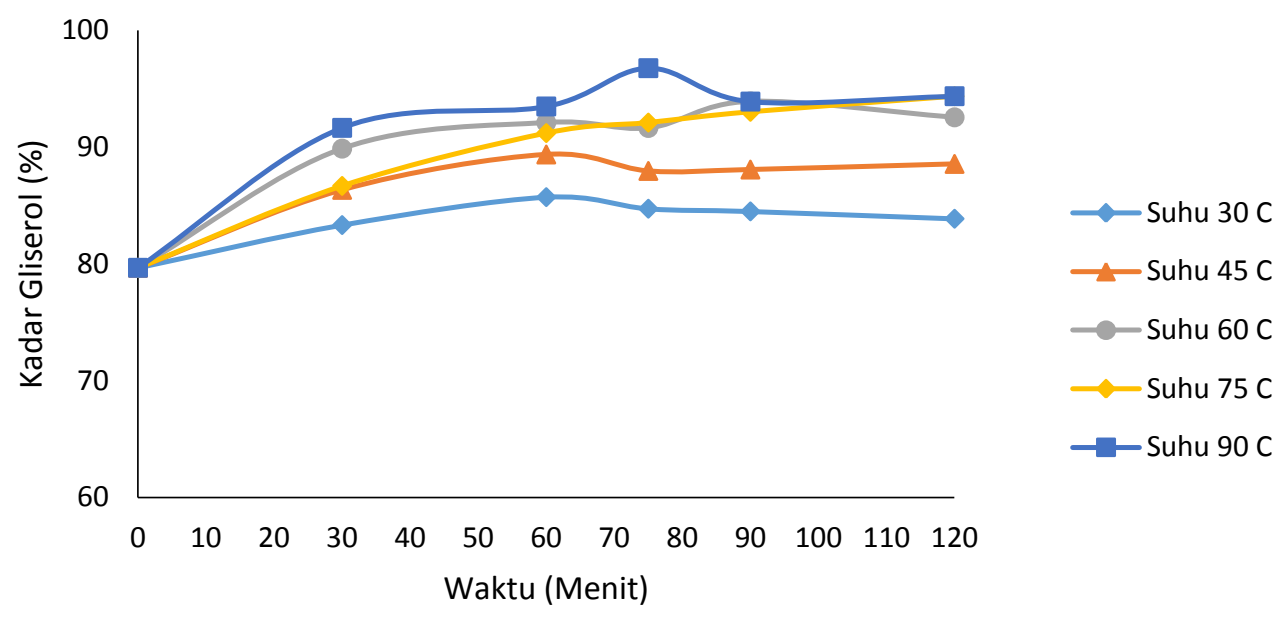

Gambar 1. Pengaruh variasi waktu dan suhu terhadap kadar gliserol

Semakin lama waktu adsorpsi, maka kemampuan adsorpsi sekam padi semakin baik (Gambar 1). Pada waktu 30 menit (suhu 30 $\left.{ }^{\circ} \mathrm{C}\right)$ konsentrasi gliserol yang dihasilkan $83.32 \%$. Konsentrasi gliserol meningkat seiring lamanya waktu adsorpsi sampai waktu 120 menit menjadi $83.86 \%$. Begitu juga pada suhu lainnya. Suhu $90{ }^{\circ} \mathrm{C}$, konsentrasi meningkat dari $91.64 \%$ menjadi $94.35 \%$. Hal ini disebabkan lamanya waktu adsorpsi akan memberikan kesempatan adsorpen dan senyawa pengotor untuk berinteraksi, sehingga senyawa pengotor yang terserap menjadi lebih banyak dan konsentrasi gliserol yang dihasilkan menjadi lebih besar. Kecendrungan ini agak berbeda pada waktu 60 dan 75 menit, kadar gliserol cenderung stabil dan sedikit mengalami penurunan. Hal ini dapat disebabkan karena dengan terlalu lamanya waktu adsorpsi dapat menyebabkan sebagian besar gliserol justru teradsorpsi oleh karbon aktif itu sendiri (Aziz et al., 2008). Selain itu dengan semakin meningkatnya waktu adsorpsi, maka kemungkinan sisi aktif atau pori-pori karbon aktif telah jenuh oleh senyawa pengotor yang teradsorpsi, sehingga tidak mampu mengadsorpsi kembali senyawa pengotor yang lain (Aziz et al., 2014).

Pengaruh suhu adsorpsi menunjukkan bahwa seiring meningkatnya suhu adsorpsi, maka kemampuan adsorpsi karbon aktif sekam padi semakin baik, ditunjukan dengan meningkatnya kadar gliserol dari suhu $30{ }^{\circ} \mathrm{C}$ hingga $90{ }^{\circ} \mathrm{C}$. Contohnya suhu $30{ }^{\circ} \mathrm{C}$ hingga 90 ${ }^{\circ} \mathrm{C}$ pada menit 75 , kadar gliserol naik dari $84.72 \%$ menjadi $96.75 \%$. Peningkatan suhu akan meningkatkan energi kinetik atau kecepatan gerak partikel dalam sistem sehingga semakin banyak tumbukan antar partikel dalam sistem, termasuk antar adsorbat (senyawa yang diserap) dengan adsorben (penyerap) (Hidayat et al., 2010). Pada penelitian ini didapatkan kondisi waktu dan suhu adsorpsi yang optimum yaitu pada suhu $90{ }^{\circ} \mathrm{C}$ selama 75 menit dengan kadar gliserol sebesar $96.75 \%$.

\section{Pengaruh Konsentrasi Adsorben}

Kadar gliserol hasil adsorpsi dari 79.66\% pada konsentrasi adsorben 0\% naik menjadi $96.75 \%$ pada konsentrasi adsorben 20\% (Gambar 2). Hal ini menunjukkan bahwa dengan semakin meningkatnya konsentrasi atau massa adsorben yang digunakan pada proses adsorpsi, maka meningkat pula kemampuan adsorpsi senyawa pengotor pada gliserol, sehingga menghasilkan kadar gliserol yang semakin tinggi. Hal ini dapat disebabkan karena dengan semakin besar konsentrasi atau massa adsorben maka semakin banyak media untuk adsorbat terdifusi ke permukaan adsorben tersebut (Nadir and Marlinda, 2013). Semakin besar konsentrasi atau massa adsorben maka semakin luas permukaan dan semakin banyak sisi aktif dari adsorben tersebut yang dapat berinteraksi dengan adsorbat, sehingga kapasitas untuk menjerap senyawa pengotor dari gliserol akan semakin besar pula.

Pada penelitian ini konsentrasi atau massa adsorben optimum untuk proses adsorpsi senyawa pengotor dalam gliserol adalah pada konsentrasi $20 \%$ dengan kadar gliserol sebesar $96.75 \%$. Konsentrasi di atas 
$20 \%$ menunjukkan penurunan kadar gliserol, hal ini disebabkan karena jumlah sisi aktif yang lebih banyak dibandingkan dengan jumlah adsorbat, sehingga terdapat sebagian besar gliserol yang ikut teradsorpsi oleh adsorben tersebut (Aziz et al., 2008).

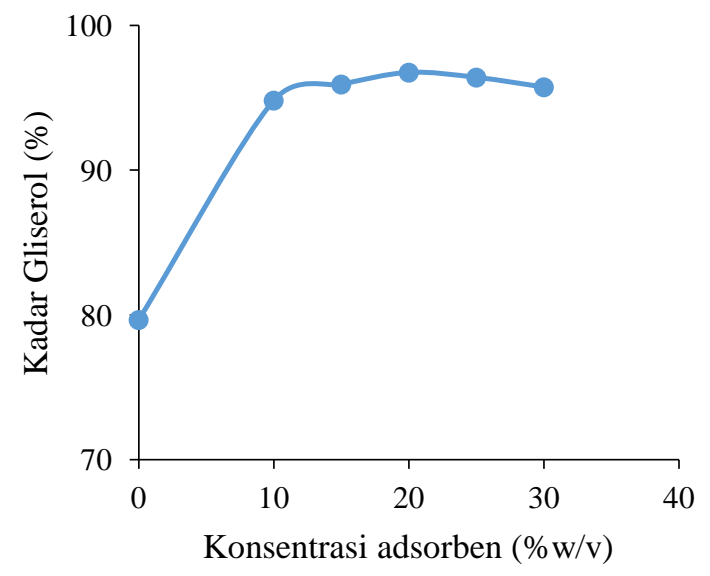

Gambar 2. Pengaruh konsentrasi adsorben terhadap kadar gliserol

\section{Pengaruh Ukuran Partikel Adsorben}

Gambar 3 menunjukkan bahwa pada ukuran partikel adsorben paling kecil yaitu 180 $\mu \mathrm{m}$, menghasilkan kadar gliserol paling besar 97.290\%. Hal ini disebabkan karena efisiensi penyerapan akan semakin meningkat dengan semakin kecilnya ukuran partikel adsorben. Semakin kecil ukuran media yang digunakan, semakin luas permukaan bidang kontak, sehingga dapat mempercepat proses adsorpsi yang terjadi.

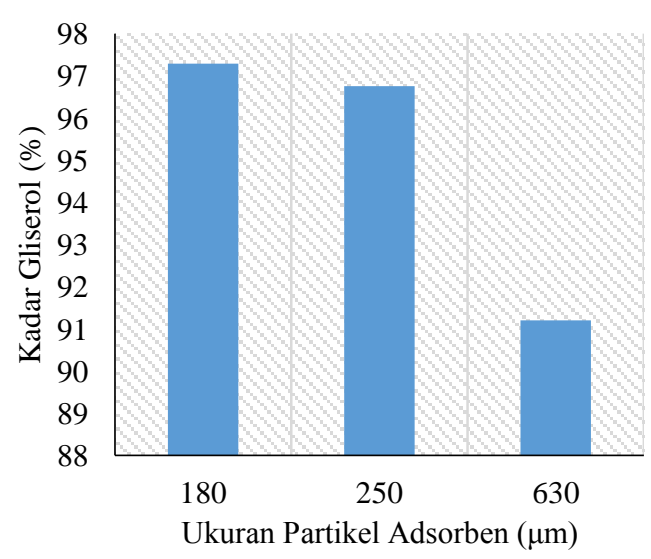

Gambar 3. Kadar gliserol pada masing-masing ukuran partikel adsorben

\begin{abstract}
Analisis Kualitas Crude Glycerol
Hasil analisis kualitas crude glycerol pada Tabel 1 menunjukkan bahwa crude glycerol setelah proses adsorpsi pada kondisi optimum memiliki kualitas yang memenuhi standar SNI 06-1564-1995. Hal ini menunjukkan bahwa proses adsorpsi menggunakan biosorben sekam padi mampu meningkatan kualitas crude glycerol tersebut. Kadar gliserol naik dari $52.950 \%$ menjadi $97.290 \%$. Hal ini menunjukkan bahwa sekam padi mampu menyerap sebagian besar senyawa pengotor dalam crude glycerol seperti air, abu dan senyawa organik lainnya.
\end{abstract}

Tabel 1. Hasil analisis kualitas crude glycerol

\begin{tabular}{llccc}
\hline No. & \multicolumn{1}{c}{ Jenis Uji } & $\begin{array}{c}\text { Gliserol } \\
\text { Sebelum } \\
\text { Adsorpsi }\end{array}$ & $\begin{array}{c}\text { Gliserol Sesudah } \\
\text { Adsorpsi }\end{array}$ & $\begin{array}{c}\text { SNI } \\
\text { 06-1564-1995 }\end{array}$ \\
\hline 1. & Kadar Gliserol (\%) & $79.660 \pm 0.019$ & $97.290 \pm 0.003$ & Min. 80 \\
2. & Kadar Air (\%) & $15.840 \pm 0.000$ & $1.698 \pm 0.000$ & Maks. 10 \\
3. & Kadar Abu (\%) & $3.160 \pm 0.000$ & $0.885 \pm 0.000$ & Maks. 10 \\
4. & Kadar MONG (\%) & $1.340 \pm 0.021$ & $0,132 \pm 0.004$ & Maks. 2.5 \\
5. & Massa Jenis (g/mL) & $1.172 \pm 0.000$ & $1.253 \pm 0.000$ & Tidak disyaratkan \\
6. & Kadar Gula & Negatif & Negatif & Negatif \\
7. & Kadar Logam K (ppm) & 43.2 & 38.5 & Tidak disyaratkan \\
\hline
\end{tabular}




\section{Karakterisasi Adsorben Menggunakan FTIR}

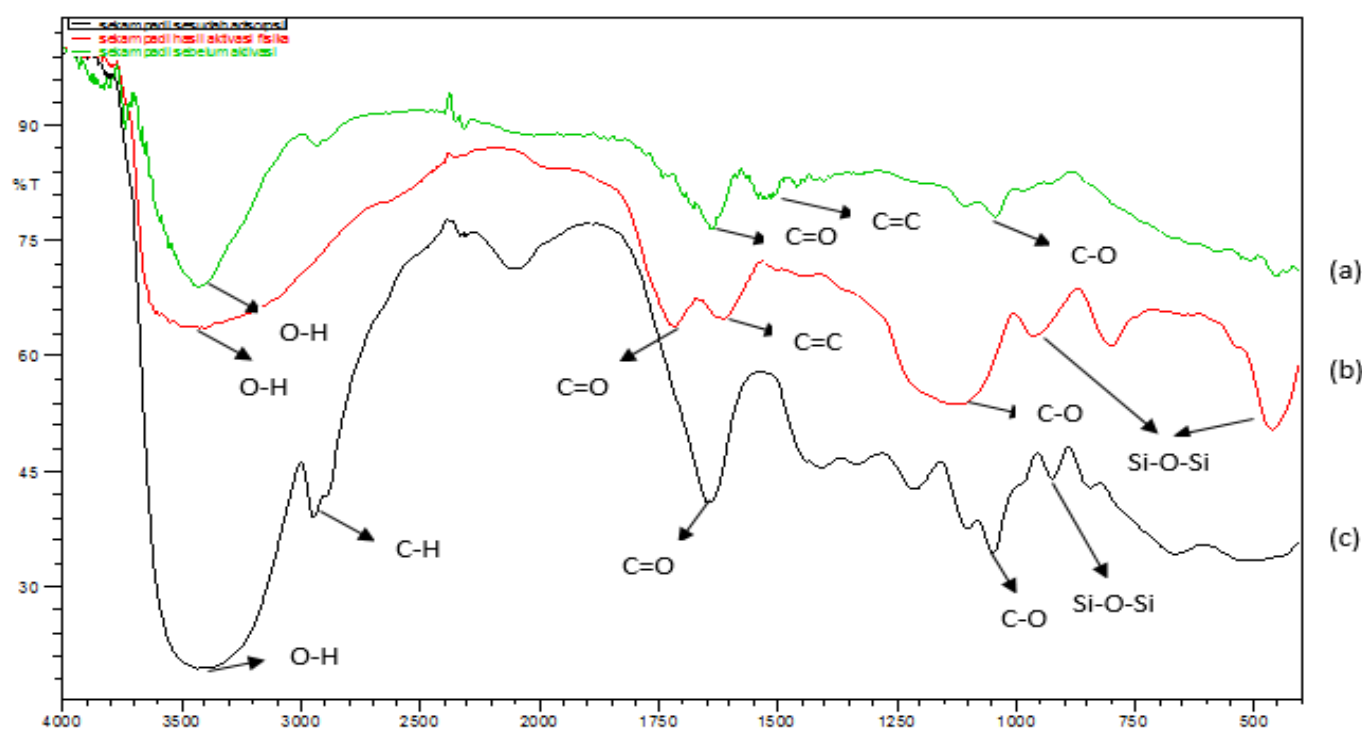

Gambar 4. (a) Spektrum FTIR adsorben sebelum aktivasi (b) adsorben sesudah aktivasi (c) adsorben sesudah adsorpsi

Karakterisasi adsorben menggunakan FTIR digunakan untuk mengetahui perubahan gugus fungsi yang dimiliki oleh adsorben tersebut sebelum aktivasi, sesudah aktivasi dan sesudah adsorpsi. Spektrum FTIR adsorben sekam padi sebelum aktivasi (Gambar 4a) menunjukan adanya beberapa pita serapan pada bilangan gelombang 3414 , 1625,1521 dan $1043 \mathrm{~cm}^{-1}$ yang masingmasing mengidentifikasikan adanya gugus $\mathrm{O}$ $\mathrm{H}$, gugus $\mathrm{C}=\mathrm{O}$, gugus $\mathrm{C}=\mathrm{C}$, dan gugus $\mathrm{C}-\mathrm{O}$. Hasil ini sesuai dengan penelitian yang dilakukan oleh Solihudin et al. (2015), dimana spektrum FTIR sekam padi yang dihasilkan juga memiliki pita serapan pada kisaran bilangan gelombang tersebut, yaitu 3424, 1698, 1607 dan $1088 \mathrm{~cm}^{-1}$.

Proses aktivasi sekam padi (Gambar 4b) menghasilkan spektrum FTIR dengan pita serapan yang sama seperti spektrum FTIR sebelum aktivasi, namun memiliki intensitas serapan yang lebih besar, artinya gugus-gugus aktif pada sekam padi setelah proses aktivasi menjadi lebih banyak, karena ikatannya dengan senyawa anorganik maupun senyawa organik lain telah terputus akibat proses aktivasi. Selain itu setelah proses aktivasi, tampak pita serapan yang muncul pada bilangan gelombang $798 \mathrm{~cm}^{-1}$ dan $962 \mathrm{~cm}^{-1}$ serta $450 \mathrm{~cm}^{-1}$ yang merupakan pita serapan gugus $\mathrm{Si}-\mathrm{OH}$ dan $\mathrm{Si}-\mathrm{O}-\mathrm{Si}$.
Adsorben sekam padi setelah digunakan (Gambar 4c) untuk adsorpsi senyawa pengotor pada gliserol menghasilkan spektrum FTIR yang cukup berbeda dari sebelum proses adsorpsi, dimana gugus $\mathrm{O}-\mathrm{H}$ dan gugus $\mathrm{C}=\mathrm{O}$ memiliki pita serapan yang sangat besar, selain itu adanya serapan pada bilangan gelombang $2943 \mathrm{~cm}^{-1}$ yang merupakan pita serapan untuk $\mathrm{C}-\mathrm{H}$ alifatik atau alkana dan juga pada $1047 \mathrm{~cm}^{-1}$ untuk ikatan C-O. Semakin besarnya pita serapan gugus $\mathrm{O}-\mathrm{H}$ dan $\mathrm{C}=\mathrm{O}$, serta munculnya gugus $\mathrm{C}-\mathrm{H}$ alifatik menunjukan bahwa adanya senyawa pengotor pada gliserol yang diadsorpsi oleh adsorben sekam padi, dimana senyawa-senyawa pengotor ini memiliki gugus-gugus fungsi yang muncul pada spektrum FTIR. Asam lemak bebas dan juga sabun yang merupakan pengotor pada gliserol memiliki gugus fungsi $\mathrm{C}=\mathrm{O}, \mathrm{C}-\mathrm{O}, \mathrm{O}-\mathrm{H}$ dan juga $\mathrm{C}-\mathrm{H}$ alifatik. Metanol memiliki gugus fungsi $\mathrm{O}-\mathrm{H}$ dan $\mathrm{C}-\mathrm{H}$ alifatik, sedangkan air memiliki gugus fungsi $\mathrm{O}-\mathrm{H}$.

\section{Karakterisasi Adsorben Menggunakan SEM}

Karakterisasi adsorben sekam padi menggunakan SEM dalam penelitian ini untuk mengetahui bentuk morfologi permukaan dan pori dari adsorben sebelum dan sesudah adsorpsi. 

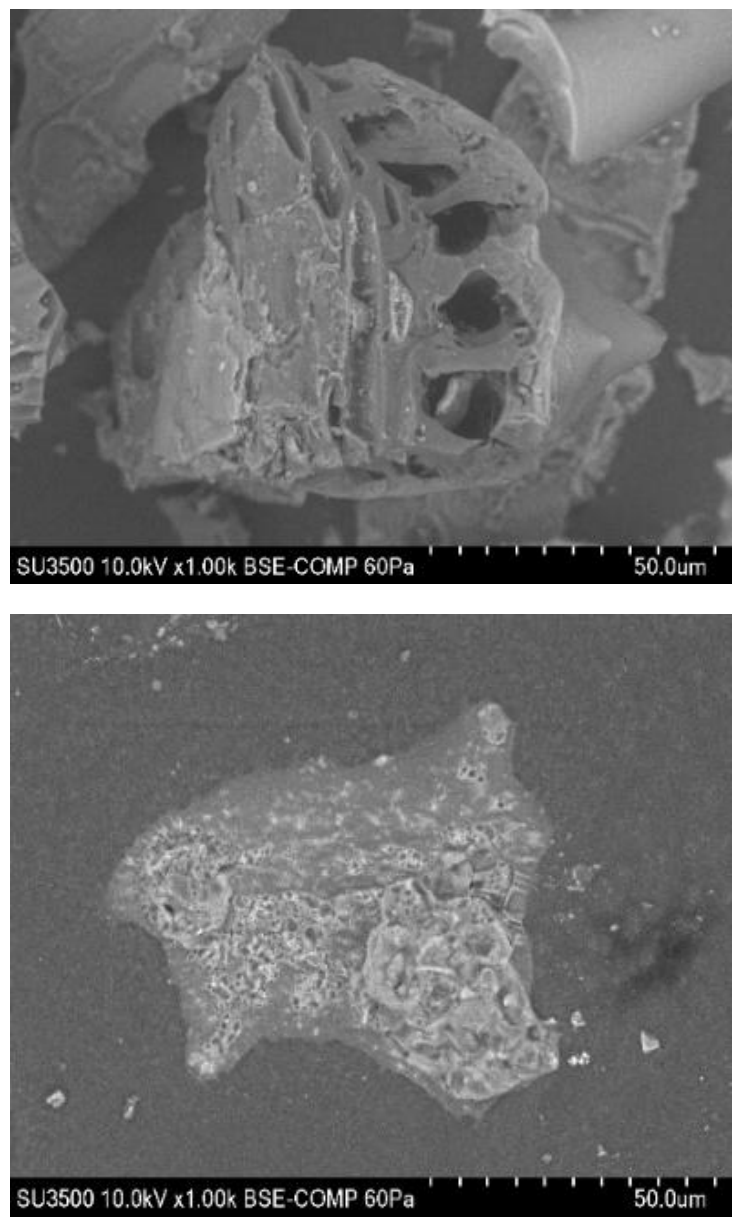

Gambar 5. Morfologi adsorben sebelum adsorpsi perbesaran 1.000x (atas), morfologi adsorben sesudah adsorpsi perbesaran $1.000 x$ (bawah)

Gambar 5 dapat dilihat bentuk morfologi adsorben sebelum dan sesudah adsorpsi. Sebelum adsorpsi terlihat adanya pori-pori pada adsorben yang cukup besar. Pori-pori ini terbentuk secara alami pada adsorben karbon aktif sekam padi, karena pada dasarnya merupakan material berpori. Melalui proses aktivasi fisika, pori-pori tersebut dapat lebih terbuka, karena senyawa tar maupun pengotor pada karbon aktif dapat dihilangkan. Adsorben setelah proses adsorpsi terlihat adanya perbedaan bentuk permukaan atau morfologi dari adsorben sekam padi tersebut, dimana pori-pori adsorben sekam padi menjadi lebih tertutup. Hal ini menunjukkan bahwa adanya senyawa pengotor (adsorbat) dalam crude glycerol yang terjerap pada proses adsorpsi seperti sabun, air, metanol, katalis dan juga asam lemak bebas, dimana senyawa- senyawa tersebut membentuk suatu ikatan dengan sisi aktif pada permukaan adsorben sehingga membentuk lapisan baru dan menutupi pori-pori adsorben sekam padi tersebut (Nurdiansah dan Susanti, 2013).

\section{SIMPULAN}

Berdasarkan hasil penelitian dapat disimpulkan bahwa kondisi optimum adsorpsi senyawa pengotor dalam crude glycerol hasil ekstraksi menggunakan sekam padi teraktivasi adalah pada suhu $90{ }^{\circ} \mathrm{C}$, waktu 75 menit, konsentrasi adsorben $20 \%(\mathrm{w} / \mathrm{v})$ dan ukuran partikel adsorben $180 \mu \mathrm{m}$ dengan kadar gliserol yang dihasilkan sebesar $97.290 \%$.

Spektrum FTIR adsorben sebelum adsorpsi menunjukan adanya gugus $\mathrm{O}-\mathrm{H}, \mathrm{C}=\mathrm{O}$, $\mathrm{C}=\mathrm{C}$ dan $\mathrm{C}-\mathrm{O}$ dan setelah adsorpsi terjadi penambahan gugus $\mathrm{C}-\mathrm{H}$ alifatik. Morfologi adsorben sebelum adsorpsi memperlihatkan pori-pori yang terbuka dan setelah adsorpsi pori-pori tersebut tertutupi oleh senyawa pengotor.

Kualitas gliserol hasil adsorpsi pada kondisi optimum telah memenuhi standar SNI 06-1564-1995 dengan kadar gliserol 97.290\%; kadar air $1.698 \%$; kadar abu $0.885 \%$; kadar MONG $0.132 \%$ dan tidak mengandung gula. Massa jenis gliserol sebesar $1.253 \mathrm{~g} / \mathrm{mL}$ dan kadar logam kaliumnya 38.5 ppm.

\section{UCAPAN TERIMAKASIH}

Pada kesempatan ini penulis menyampaikan terimakasih kepada Pusat Penelitian dan Penerbitan LP2M UIN Syarif Hidayatullah Jakarta yang telah mendanai penelitian ini. Kepada Nita Rosita dan Wahyu Permata (PLP Laboratorium Lingkungan PLT UIN Syarif Hidayatullah Jakarta) yang telah membantu dalam penelitian ini.

\section{DAFTAR PUSTAKA}

Adhani L, Aziz I, Nurbayti S, Octavia CA. 2016. Pembuatan biodiesel dengan cara adsorpsi dan transesterifikasi dari minyak goreng bekas. Jurnal Kimia Valensi. 2(1): 71-82.

AOAC. 1995. Official Methods of Analysis of The Association of Analytical Chemists. Washington D.C. 
Atkins PW. 1998. Phisical Chemistry, $6^{\text {th }}$ ed. Oxford(UK): Oxford University Press

Aziz I, Nurbayti S. Luthfiana F. 2008. Pemurnian gliserol dari hasil samping pembuatan biodiesel menggunakan bahan baku minyak goring bekas. Jurnal Kimia Valensi. 1(3): 157-162.

Aziz I, Las T, Shabrina A. 2014. Pemurnian crude glycerol dengan cara pengasaman dan adsorpsi menggunakan zeolit alam lampung. Chem. Prog.7: 66-73.

Fadhillah NHB, Aziz I, Hendrawati. 2017. Penggunaan $\mathrm{H}$-zeolit dan tawas dalam pemurnian crude glycerol dengan proses adsorpsi dan koagulasi. Jurnal Kimia Valensi. 3(1): 35-43.

Hidayat Y, Wibowo AH, Sulistyowati. 2010. Studi adsorpsi larutan gliserol menggunakan zaa sebagai model pemisahan gliserol pada limbah produk biodiesel. Jurnal Ekosains. 2(3): 14-20.

Manosak R, Siripong L, Mali H. 2011. Sequential-refening of crude glycerol derived from waste used-oil methyl ester plant via a combined process of chemical and adsorption. Fuel Processing Technology. 92: 92-99.

Nadir M, Marlinda. 2013. peningkatan kadar gliserol hasil samping pembuatan biodiesel dengan metode adsorpsi asam lemak bebas (ALB) menggunakan fly ash. Konversi. 2(2): 1-8.

Nurdiansah H, Susanti D. 2013. Pengaruh variasi temperatur karbonisasi dan temperatur aktivasi fisika dari elektroda karbon aktif tempurung kelapa dan tempurung kluwak terhadap nilai kapasitansi electric double layer capacitor (EDLC). Jurnal Teknik Pomits. 2(1): 13-18.

Nurhasni, Hendrawati, Saniyyah N. 2014. Sekam padi untuk menyerap ion logam tembaga dan timbal dalam air limbah. Jurnal KimiaValensi. 4(1): 36-44.

SNI06-1564-1995. Gliserol Kasar. Jakarta (ID): Badan Standarisasi Nasional.

Solihudin, Noviyanti AR, Rukiah. 2015. Aktivasi arang sekam padi dengan larutan natrium karbonat dan karakterisasinya. Chimica et Natura Acta. 3(1): 11-16. 